\title{
O CAMINHO BRASILEIRO PARA O FASCISMO
}

\author{
Armando Boito Jr.*
}

\begin{abstract}
$\mathrm{O}$ artigo analisa a natureza do governo Bolsonaro, da sua base social de apoio mais ativa e da crise política que lhe deu origem. Polemiza com a bibliografia clássica e atual sobre o fascismo e, operando com um conceito de fascismo inserido na tradição marxista, caracteriza o governo e sua base social como (neo)fascistas. Sustenta a necessidade de construir uma tipologia das crises políticas nas sociedades capitalistas e procura mostrar que a natureza e a dinâmica da crise política brasileira de 2015-2018 são típicas da crise política que dá origem ao fascismo. Insere o bolsonarismo no contexto da democracia ainda existente no Brasil, que caracteriza como uma democracia burguesa em crise.

Palavras-CHAvE: Política Brasileira. Governo Bolsonaro. Neofascismo. Crise Política.
\end{abstract}

A crise política brasileira, iniciada em novembro de 2014 - quando o Partido da Social Democracia Brasileira (PSDB) impetrou duas ações judiciais visando a anular o resultado da eleição de outubro daquele ano -, passou por várias fases e levou o país, em outubro de 2018, a um governo em que predomina um grupo político neofascista.

A primeira pergunta que a afirmação anterior suscita é a de saber por que deveríamos caracterizar o bolsonarismo como uma variante do fascismo. Há uma onda de movimentos e governos de extrema-direita em diversas regiões do mundo. No nosso entendimento, nem todos eles podem ser caracterizados como fascistas, mas o governo Bolsonaro, sim. Qual o motivo dessa particularidade? Por que não caracterizar o bolsonarismo um "populismo de direita”? Afinal, afirmam alguns observadores e estudiosos, o fascismo deve ser considerado um fenômeno político muito particular, da-

* Universidade Estadual de Campinas (Unicamp) Cidade Universitária Zeferino - rua Cora Coralina no 100 Distrito de Vaz Barão Geraldo. CEP: 13083-896. Campinas - SP - Brasil. armando.boito@gmail.com

http://orcid.org/0000-0002-1826-7331 tado e, definitivamente, pretérito. A segunda pergunta que a mesma afirmação suscita é a de saber se existe, de fato, uma relação entre, de um lado, as características da crise política iniciada em 2014 e, de outro, o surgimento e a vitória eleitoral do movimento bolsonarista. Ou seja, a crise política apresenta características que explicam o nascimento e a vitória de um movimento fascista na semiperiferia do capitalismo?

Neste texto, tentaremos oferecer alguns elementos de resposta para essas duas ordens de questões: por que falar em fascismo e por que se pode sustentar que a crise política iniciada em 2014 apresenta características que explicam o surgimento e a vitória que o fascismo obteve no Brasil. Utilizaremos, para tanto, as pesquisas empíricas que temos feito sobre política brasileira contemporânea, bem como a bibliografia clássica e contemporânea, principalmente a marxista, sobre o fascismo original e, especialmente, a análise que Nicos Poulantzas desenvolve em seu livro Fascismo e ditadura (Poulantzas, 1970). Como o leitor verá, esse livro ocupa um lugar central nas nossas reflexões. 


\section{O FASCISMO ORIGINAL E O NEO- FASCISMO}

Por que lançar mão, um século após a criação do Fasci italiani di combattimento, no ano de 1919, do conceito de fascismo?

Inspirados na análise de autores como Palmiro Togliatti e Nicos Poulantzas, sustentamos a legitimidade teórica de um conceito geral de fascismo, isto é, um conceito de fascismo que transcenda as particularidades do fascismo original, italiano ou alemão (Poulantzas, 1970; Togliatti, 2010). ${ }^{1}$ Boa parte da bibliografia, marxista e não marxista, recusa a ideia de tal conceito. Pretendem colar inseparavelmente o conceito de fascismo ao movimento dirigido por Mussolini e por Hitler e à ditadura que foi implantada na Itália e na Alemanha no entreguerras - vários autores recusam até a utilização de um mesmo conceito para designar os movimentos e as ditaduras da Itália e da Alemanha. Dispensam a esse fenômeno um tratamento epistemológico muito diferente daquele que dispensam a outros fenômenos referentes, como o fascismo, à maneira de organização do poder político. Discorrem sobre os conceitos de democracia, ditadura, monarquia, república e outros, transitando livremente da Grécia Antiga e da Europa feudal à Europa contemporânea, e da Europa à Ásia e à América, tratando tais conceitos pelas suas características gerais, abstraindo as formas específicas como se reaస్․ lizam em diferentes lugares e épocas, mas não N aceitam que se aproxime Plínio Salgado ou Jair Bolsonaro de Benito Mussolini. ${ }^{2}$

Pois bem, Togliatti define o fascismo como um regime político reacionário de massa, e Poulantzas o define como um dos regimes políticos que a forma de Estado capitalista de

${ }^{1} \mathrm{O}$ livro de Togliatti reúne as conferências por ele pronunciadas em Moscou ao longo do primeiro semestre de 1935. Há edições mais antigas das Lezioni, mas essa de 2010 é mais completa.

${ }^{2}$ Um livro bem recente e que tem como objetivo central recusar qualquer conceito geral de fascismo é o de Emilio Gentile (2019), historiador da Itália fascista. Polemizei com posição semelhante presente na bibliografia marxista (Boito Junior, 2019). exceção pode assumir - os outros regimes dessa forma de Estado seriam a ditadura militar e o regime bonapartista. Conforme veremos, as definições de Togliatti e de Poulantzas podem ser unificadas. Cito a seguir passagens ilustrativas da análise desses dois autores.

O segundo elemento consiste no caráter de massa das organizações do fascismo. Muitas vezes o termo fascismo é usado de modo impreciso, como sinônimo de reação, terror etc. Isso não é correto. O fascismo não significa apenas a luta contra a democracia burguesa; nós não podemos usar essa expressão quando estamos na presença apenas dessa luta. Devemos usá-la apenas quando a luta contra a classe operária se desenvolve sobre nova base de massa de caráter pequeno-burguês, como vemos na Alemanha, na Itália, na França, na Inglaterra e em toda parte que existe um fascismo típico (Togliatti, 2010, p. 8, tradução nossa).

O primeiro problema que se coloca no estudo do fascismo é o de sua especificidade em relação às formas de regime tais como a ditadura militar e o bonapartismo e em relação a outras formas de Estado capitalista. Dito de outro modo, podemos definir uma forma de Estado capitalista de exceção que, ela própria, recobre diversas formas específicas de regimes de exceção, tais como o fascismo, as ditaduras militares e o bonapartismo? (Poulantzas, 1970, p. 12, tradução nossa).

Que definições são essas? Elas são definições que poderíamos denominar teóricas e sintéticas, e não definições que denominaríamos descritivas, como o são aquelas que encontramos em muitos autores que tratam da questão. De fato, é muito comum, no estudo do fascismo, historiadores e intelectuais, motivados pelo objetivo de chegar a uma caracterização geral do fenômeno, enumerarem numa lista maior ou menor diversos atributos que caracterizariam o fascismo. Umberto Eco (2017) enumera um a um quatorze atributos: culto da tradição, recusa da modernidade, irracionalismo, ação pela ação, medo da diferença, apelo aos setores médios, nacionalismo, elitismo e outras. Robert O. Paxton, no seu importante trabalho Anatomy of fascism, chega, após longo exame histórico, a uma definição do fascismo como comportamento político marcado por um conjunto de 
cerca de vinte atributos (Eco, 2017; Paxton, 2004). Em tais definições, não estão claros os critérios teóricos a partir dos quais são selecionados este ou aquele atributo, e não outros; não se sabe por que se chega a cinco, dez ou vinte atributos a serem retidos no conceito e nada se diz sobre o que é principal e o que é secundário. No final das contas, o conceito assim obtido serve muito pouco como instrumento analítico - cada fenômeno histórico considerado sempre apresentará parte, e não a totalidade dos atributos contidos no conceito. Faço duas observações para ilustrar o problema.

Umberto Eco não arrola a assim denominada liderança carismática como atributo importante do fascismo e, no entanto, se partíssemos de uma perspectiva weberiana, saltaria à vista que o atributo fundamental a ser destacado no fascismo seria esse tipo de liderança, pois, além da extrema personalização da liderança de Mussolini e de Hitler na política fascista, esse conceito ocupa lugar destacado na teoria weberiana, qualificando uma das três formas de dominação legítima. Robert $\mathrm{O}$. Paxton, por sua vez, quando sistematiza a definição de fascismo na conclusão do seu livro, não alude à natureza de classe do fenômeno e, no entanto, partindo - como nós mesmos partimos neste texto - de uma perspectiva marxista, o caráter pequeno-burguês desse movimento será valorizado, dado o critério teórico marxista que conduz a perguntar, acima de tudo, pela natureza de classe dos fenômenos políticos. Porém as definições que estamos denominando descritivas são empiricistas. Aqueles que as elaboram acreditam partir, direta e exclusivamente, dos fatos brutos, sem se apoiar em critério teórico prévio. Robert O. Paxton é taxativo nessa matéria. Afirma que parte direta e exclusivamente dos casos conhecidos de fascismo para, selecionando atributos comuns, chegar a uma definição geral. O que ele não explica é como poderá selecionar "os casos conhecidos de fascismo" se ele não tem, já no início da pesquisa, uma indicação, por mais geral e simples que seja, do conceito de fascismo - na verdade, parte-se de uma "generalidade", e não exclusivamente do fato histórico, para utilizar o conceito de "generalidade" com o qual Louis Althusser faz a crítica ao empiricismo (Althusser, 1965).

Tanto na definição de Togliatti quanto na de Poulantzas, e diferentemente das definições empiricistas criticadas anteriormente, mobiliza-se conscientemente, para caracterizar o fascismo, a teoria marxista do Estado - o Estado como organizador da dominação de classe, a democracia e a ditadura como formas de Estado etc. Parte-se, simultaneamente, dessa teoria e das informações empíricas disponíveis sobre fenômenos políticos que, por alguns indicadores fornecidos pela citada teoria, podem, pelo menos inicialmente, ser agrupados sob um conceito comum. Chega-se a uma definição teórica e, também, sintética, definição que não se dispersa em inúmeros detalhes, destaca o que é essencial no fenômeno, e, é verdade, serve muito mais como um guia seguro e esclarecedor para a análise que como uma caracterização detalhada do fenômeno. Isso se passa dessa forma na definição de todos os conceitos do materialismo histórico: o Estado é a instituição que organiza a dominação de classe; o capital é o valor que se valoriza; classe social é o coletivo que ocupa uma mesma posição no processo de produção etc. Cada uma dessas definições são teoricamente informadas - dependem de outros conceitos como os de dominação de classe, valor, acumulação, relações de produção etc. -, são sintéticas e exigem, para que se produza conhecimento sobre os fenômenos aos quais se referem, o desenvolvimento do conjunto da análise do fenômeno inicialmente definido.

Voltemos ao conceito de fascismo. As duas definições, a de Togliatti e a de Poulantzas, convergem para este ponto: o fascismo é uma ditadura cujo regime político é um regime reacionário de massa. Tanto para uma quanto para outra, um regime de ditadura militar que, como tal, não possui base de massa minimamente organizada não é, como ambos desta- 
cam nas passagens que citamos, uma ditadura de tipo fascista, mesmo que tal ditadura tenha sido instituída, como alerta a passagem citada de Togliatti, para combater o movimento operário. Acrescentemos algo importante para nós, que analisamos o Brasil. Interessa destacar que, se o fascismo é esse regime político, também deve ser denominado fascista o movimento social que luta pela instauração desse regime e a ideologia que mobiliza esse movimento e legitima a ditadura fascista. No Brasil, não temos uma ditadura fascista - estamos escrevendo em outubro de 2019 -, mas temos um movimento e uma ideologia fascistas que, dentro dos limites dados pela correlação política de forças existente, atenta contra a democracia burguesa e pode, dependendo da dinâmica da conjuntura, chegar à instauração de uma ditadura de tipo fascista no Brasil.

Faz-se necessária agora uma primeira desagregação ou desenvolvimento da definição da qual estamos partindo. A mencionada massa do "regime político reacionário de massa" não é um aglomerado amorfo com composição social aleatória, mas, sim, uma massa predominantemente pequeno-burguesa no fascismo original e predominantemente de classe média, conforme veremos, no neofascismo brasileiro. Os estudos marxistas clássicos sobre o fascismo original destacaram o caráter de classe pequeno-burguês do movimento. ${ }^{3}$ É certo que o fascismo ampliou muito sua base $\vec{\delta}$ original, mas a base precursora e principal foi i essa e assim seguiu sendo - era, por exemplo, o segmento social que mais fornecia quadros đิ para o partido fascista e nazista. Um elemento กั

ㄱ 3 O caráter pequeno-burguês do movimento fascista ori¿. ginal é afirmado e demonstrado por inúmeros autores marxistas com base em ampla documentação e com es๗ tatísticas de diversos tipos - geografia do voto, composi-

$>$ ção dos partidos fascista e nazista etc. Além dos textos de

i. Togliatti (2010) e Poulantzas (1970), vale a pena citar, e obedecendo a ordem cronológica de aparição, "I due fas-

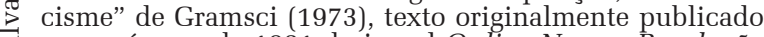

๙్ num número de 1921 do jornal Ordine Nuovo; Revolução

e contra-revolução de Leon Trotsky ([1933] 1968); Fascisme

I

J lhando com outras problemáticas e teorias, também sus-

tentam o caráter pequeno-burguês do fascismo original o

trabalho de Wilhelm Reich ([1936] 1972), sobre a psico-

logia de massa do fascismo, e o de Barrington Moore Jr.

(1987) sobre as bases sociais da obediência e da revolta. mencionado, mas não suficientemente destacado pelos estudos marxistas clássicos, é a significativa presença no movimento e nos partidos fascistas daquele segmento social que, décadas depois, seria conhecido como classe média. ${ }^{4}$ Barrington Moore Jr., no seu alentado trabalho intitulado Injustiça: as bases sociais da obediência e da revolta, é um dos autores que dá importância à presença da classe média, tanto do setor público quanto do setor privado, na base do movimento e no coletivo de militantes e de dirigentes do partido nazista. Ele utiliza estatísticas detalhadas sobre a composição socioprofissional do partido nazista produzidas pelo próprio partido. Compara a presença dos grupos socioprofissionais no partido com o peso de cada um deles na população economicamente ativa. Em conclusão, rechaça as tentativas de negar o caráter pequeno-burguês do movimento e do partido, destaca a participação dos profissionais de classe média e acrescenta que o partido chegou a recrutar entre trabalhadores manuais da indústria, embora esse segmento estritamente operário estivesse sub-representado no coletivo partidário. Interessa-nos mais o que ele diz sobre a presença da classe média no movimento e no partido nazista. Afirma o autor que o NSDAP, a sigla alemã do Partido Nacional Socialista dos Trabalhadores Alemães, representou

um especial apelo para os trabalhadores de colarinho branco gerados pela sociedade industrial adiantada, graças à posição insegura desses trabalhadores [...] dependentes da administração [...] [e dos] salários como os operários da produção. No entanto, ao mesmo tempo, os trabalhadores de colarinho branco efetuam funções "limpas" ou não-manuais em um escritório, o que os deixa mais próximos da administração e encoraja a tendência a olharem os operários com desprezo, sem deixarem de temê-los. [...] No todo, as características sociais

${ }^{4}$ Embora Hilferding (1985), em seu estudo clássico sobre o capital financeiro publicado em 1910, já tivesse se debruçado sobre esse segmento que denominou "nova classe média”, destacou que se tratava de um segmento que crescia mais que a classe operária e que se distinguia por possuir uma carreira, estar integrado ou mais próximo da administração da empresa e usufruir de uma remuneração superior à do trabalhador manual, atributos que induziriam ao individualismo (p. 325-327) 
do Grupo 1 [pequena burguesia proprietária e classe média, $\mathrm{ABJ}$ ] confirmam a tese familiar, embora intermitentemente questionada, de que o NSDAP [Partido Nacional Socialista dos Trabalhadores Alemães] exercia maior atração sobre as classes médias baixas. Os ressentimentos que, de acordo com tais evidências, alimentaram o movimento nazista eram aqueles do "homem comum" (little man) irado face às injustiças de uma ordem social que [o] ameaçava ou não conseguia recompensar as virtudes do trabalho árduo e da abnegação à medida que esses esforços pessoais tornavam-se cristalizados na loja do comerciante, no lote do camponês, na habilidade manual do artesão, no emprego de colarinho branco e nos dons do técnico ou do jornalista (Moore Junior, 1987, p. 547-554).

O fascismo, em geral, é um movimento reacionário de massa enraizado em classes intermediárias das formações sociais capitalistas. No fascismo original, a base social era composta majoritariamente por pequenos proprietários, a pequena burguesia; no neofascismo brasileiro do século XXI, essa base social é composta majoritariamente pela classe média e, particularmente, pela alta classe média. ${ }^{5} \mathrm{O}$ movimento neofascista e suas organizações nasceram das manifestações pelo impeachment de 2015-2016, manifestações estas que todos os levantamentos empíricos mostram que eram da alta classe média (Cavalcante; Arias, 2019; Galvão, 2016). Em 2017, o eleitorado pioneiro de Bolsonaro, como mostram as pesquisas de intenção de voto para Presidência da República realizadas ao longo daquele ano, quando o então presidenciável detinha em torno de $10 \%$ das intenções de voto, esse eleitorado era de elevada instrução formal e alta ren-

${ }^{5}$ Tanto no fascismo original quanto no neofascismo, os proprietários de terra apoiaram o movimento desde o início. Na Itália pré-fascista e no Brasil atual, os proprietários de terra estavam em situação defensiva diante das classes populares. Viviam, ao contrário dos demais segmentos da classe capitalista, sob a ameaça permanente de ocupação de sua propriedade pelos trabalhadores. Daí, sua predisposição favorável a um movimento antioperário e antipopular como o movimento fascista. As associações de proprietários rurais foram, entre os segmentos da classe dominante, pioneiras no apoio à candidatura Bolsonaro. Tratando do fascismo italiano, Gramsci (1973), no já citado texto de 1921, fala da existência de dois fascismos desde o início do movimento: um da pequena burguesia e outro dos proprietários rurais da Emilia, Toscana, Veneto e Umbria. De nossa parte, estamos diferenciando a classe social que organiza o movimento daquela que o apoia e financia. da. Mais recentemente, quando a gestão Bolsonaro já completara nove meses, os analistas de pesquisas de opinião constataram que também é nesse segmento social que se encontram os bolsonaristas mais convictos (Prandi, 2019). Os dados de 2017 mostram que a classe média é a base social precursora do bolsonarismo, enquanto os de 2019 mostram que ela é, também, sua base mais fiel. ${ }^{6}$

A ideologia fascista, como não poderia deixar de ser, traz a marca de sua base social - e aqui procedemos a uma segunda desagregação ou desenvolvimento da definição sintética da qual partimos. A ideologia fascista pequeno-burguesa ou de classe média é uma ideologia crítica, mas de perspectiva conservadora. Poulantzas (1970) fala em "anticapitalismo de status quo”; Palmiro Togliatti (2010) e Georgi Dimitroff (1965) falam, às vezes inapropriadamente, em "demagogia fascista”. O fato é que o fascismo original fazia a crítica ao grande capital, aos especuladores e aos financistas de uma perspectiva conservadora de pequeno proprietário; o neofascismo brasileiro, com predomínio da classe média, critica a corrupção e a "velha política", e o faz, no caso da corrupção, de uma perspectiva conservadora e moralista e, no caso da "velha política", de uma perspectiva autoritária que enaltece a concentração do

6 "O grupo dos mais afinados com Bolsonaro é formado pelos que votaram nele, aprovam seu mandato e concordam com suas declarações. São seus adeptos fiéis, entusiastas fanáticos, para não dizer adoradores em qualquer circunstância., Representam $12 \%$ da população com 16 anos ou mais. É o chamado grupo heavy do presidente, aquele núcleo duro de apoiadores irrestritos constituído por bolsonaristas radicais" (Prandi, 2019, p. 1). "[Esse grupo dos $12 \%$ ] não é uma fatia majoritariamente de pobres nem de desinformados, não são ignorantes inocentes. Sua presença aumenta com a renda familiar mensal medida em salários mínimos: na categoria de renda que vai até dois salários, há 5\% de entrevistados incluídos no grupo heavy. Essa taxa sobe para $15 \%$ no grupo de dois a cinco salários e vai para $23 \%$ no de cinco a dez salários, alcançando $25 \%$ na categoria que tem renda maior que dez salários mínimos por mês. Outro bom indicador de estratificação social é a escolaridade. No grupo de apoio irrestrito a Bolsonaro, estão incluídos $12 \%$ dos que tiveram o ensino fundamental como nível maior de escolaridade, $11 \%$ dos de nível médio e $16 \%$ dos que tiveram educação superior. A distribuição por cor é outro indicador que ajuda a entender melhor o grupo. Fazem parte dele 5\% dos indígenas, $8 \%$ dos pretos e igual número dos amarelos, 11\% dos pardos e $17 \%$ dos brancos. É razoável concluir que os heavy de Bolsonaro não retratam o Brasil. Pelo que se viu até aqui, o grupo pode ser representado por um homem branco de idade madura, escolarizado e de estrato social de médio para alto" (Prandi, 2019,p. 2). 
poder no Executivo e aponta para o fim da política parlamentar, isto é, para o fim da democracia burguesa. $^{7}$

O aspecto crítico do discurso fascista e neofascista pode, de maneiras distintas, obter - e de fato obtém - impacto popular que transcende sua origem de classe. Nessa matéria, há dois erros a evitar. O primeiro consiste em imaginar que o fascismo penetra indistintamente e por igual todas as classes populares e dominantes, de tal modo que poderíamos desprezar a divisão em classes para a análise do fenômeno fascista. Todos teriam sido igualmente atraídos por Hitler ou Mussolini. Esse é o erro presente em muitos textos que recorrem a Freud para analisar o fascismo, mobilizando a ideia de carência do pai protetor e autoritário para explicar o sucesso político do fascismo. ${ }^{8}$ O outro erro consiste em ignorar o impacto popular desse fenômeno. Os comunistas cometeram esse erro na luta contra o fascismo original. ${ }^{9}$ No Brasil, o neofascismo nascido na alta classe média logrou obter, ao longo do ano de 2018, apoio em segmentos populares. Foi um apoio tardio e, ao que parece, volátil - as atuais pesquisas de avaliação do governo Bolsonaro indicam que é nesses mesmos segmentos

${ }^{7}$ Convém nuançar. De um lado, o fascismo original também levantava a bandeira da luta contra a corrupção. Cito Dimitroff (1935, p. 12, tradução nossa): "O fascismo entrega o povo para ser devorado pelos elementos mais corruptos e venais, mas, antes deles, vem com a exigência de 'um governo honesto e incorruptível'. Especulando sobre a profunda desilusão das massas com governos democráti-

- cos burgueses, o fascismo denuncia hipocritamente a cor-

ปิ rupção (por exemplo, os casos Barmat e Sklarek na Alema-

N nha, o caso Stavisky na França e muitos outros)". De outro

on lado, o neofascismo também critica as elites financeiras

\& empresariais que teriam se aliado à esquerda comunis-

ta, manipuladora dos pobres desinformados, durante os

governos do PT. E exemplar nesse sentido a palestra de

\% Abraham Weintraub no Congresso Conservador (CPAC)

กิ realizado em São Paulo, em 11 e 12 de outubro de 2019.

$\neg$ Disponível em: https://www.youtube.com/watch?v=60B-

2. jYlCoDlo. Acesso em: 15 out. 2019.

ले 8 Theodor Adorno (2006) apresenta esse tipo de análise

$>$ inspirada em Freud, que ignora a natureza de classe da ô base de apoio do fascismo.

9 "Um dos aspectos mais fracos da luta antifascista de nossos T. partidos reside no fato de que eles reagem inadequada e muito - lentamente à demagogia do fascismo, e ainda hoje continuam a

I olhar com desdém para os problemas da luta contra a ideologia

f fascista. Muitos camaradas não acreditavam que uma variedade

tão reacionária da ideologia burguesa como a ideologia do fas-

cismo, que em sua estupidez frequentemente chega ao ponto da

loucura, fosse capaz de ganhar influência de massa. Este foi um

Uै grande erro" (Dimitroff, ${ }^{1935}$, p. ${ }^{77}{ }^{78}$, tradução nossa). populares que a aceitação do presidente mais perde pontos (Prandi, 2019) -, contudo foi um apoio suficiente para que Bolsonaro vencesse a eleição presidencial de 2018.

O discurso superficialmente crítico, mas profundamente conservador do fascismo, pode confundir inclusive as organizações democráticas e populares. No Brasil, parte importante do Partido dos Trabalhadores (PT), de seus dirigentes, deputados e integrantes da equipe governamental de Dilma Rousseff mostraram acreditar, por seus atos e suas palavras, que a Operação Lava Jato era, de fato, para combater a corrupção, e não uma operação que instrumentalizava politicamente a luta contra a corrupção para golpear exclusivamente empresas nacionais e o próprio PT, satisfazendo interesses e expectativas políticas do capital estrangeiro e da alta classe média. ${ }^{10}$ Essa operação mostra como os conflitos entre frações da burguesia atravessam as instituições do Estado, pois a ação de um ramo da burocracia de Estado, alinhada politicamente e dispondo de vínculos com o Departamento de Justiça dos Estados Unidos, visava a destruir, com o apoio militante da alta classe média, um ramo importante das empresas nacionais e eliminar a direção do partido de centro-esquerda, o PT, que vinha colocando obstáculos à política externa dos Estados Unidos para a América Latina. Na extrema-esquerda também vicejaram ilusões diante do discurso neofascista nascente. O Partido Socialista dos Trabalhadores Unificado (PSTU) e ao menos uma das tendências do Partido Socialismo e Liberdade (PSOL), à qual pertencia a candidata à Presidência da República em 2014, a deputada Luciana Genro, apoiaram a Operação Lava Jato, atraídos pelo discurso aparentemente crítico do neofascismo.

Trata-se de um movimento de massa da classe média e/ou da pequena burguesia que deve ser qualificado de reacionário, porque $o$ seu objetivo político principal é a eliminação

${ }^{10}$ Procuro demonstrar essa tese no meu livro sobre a crise política iniciada em 2014 (Boito Junior, 2018). 
do pensamento e dos movimentos de esquerda. No fascismo original, a esquerda eram os partidos operários de massa - o partido socialista e o partido comunista - com seus programas que apontavam para a transição ao socialismo. Nesse contexto, de polarização política intensa, o fascismo mimetizou conscientemente os comunistas e os socialistas e organizou-se também num partido de massa, sem o que, como afirmava Hitler, o movimento não poderia ser vitorioso. No neofascismo, o inimigo a ser combatido é o movimento democrático e popular, guiado por um reformismo superficial e desprovido de organização partidária de massa. Nesse novo contexto, de polarização política moderada se comparada ao cenário anterior, o neofascismo se satisfaz, até o presente momento, com a agitação nas redes sociais, o apoio das igrejas pentecostais e neopentecostais que estão - elas sim - organizadas junto à população de baixa renda e com manifestações de rua esporádicas, como as manifestações de 26 de maio e de 30 junho deste ano, em apoio ao governo Bolsonaro e ao ex-juiz Sérgio Moro.

Uma análise importante a ser desenvolvida seria mostrar como a definição teórica e sintética permite explicar elementos geralmente arrolados de forma um tanto aleatória nas definições que denominamos descritivas do fascismo. Um exemplo: arma ideológica importante para combater a esquerda é o nacionalismo bolsonarista cujo conteúdo consiste, única e exclusivamente, em designar uma suposta homogeneidade da sociedade nacional como bem maior - homogeneidade apresentada, simultânea e contraditoriamente, como algo existente e algo ainda a ser atingido. Essa homogeneidade estaria ameaçada pelas lutas da esquerda e por seus valores - luta pela terra, luta pelos direitos dos trabalhadores, luta das mulheres, dos ambientalistas, da população LGBT, dos negros, indígenas e outras. A luta democrática e popular estaria do lado de fora da nação e ameaçaria sua suposta ou almejada homogeneidade interna. A hipótese é que os demais elementos, como a crítica conservado- ra da economia e do Estado capitalista, o sentimento de ameaça vinda de baixo, sentimento de dissolução da sociedade devido à propagação de valores dissolventes, o apego a valores tradicionais, o ativismo político, o culto da violência, o irracionalismo e outras características dos movimentos fascista e neofascista, estão articulados com sua natureza de classe pequeno-burguesa e/ou de classe média numa situação de crise provocada pela percepção do agravamento do conflito de classes.

Em muitos países, os movimentos fascistas e, atualmente, os neofascistas não lograram conquistar o poder governamental ou sequer participar dele, e onde o lograram nem sempre implantaram uma ditadura fascista. Porém, em todos os países em que chegou ao poder, o fascismo o fez, não como representante dos interesses das classes intermediárias que lhe deram origem - a pequena burguesia e a classe média -, mas, sim, após ter sido politicamente confiscado pela burguesia ou uma de suas frações com o objetivo de, apoiada nesse movimento, superar uma crise política implantando um governo antidemocrático, antioperário e antipopular. A pequena burguesia e a classe média continuam politicamente ativas sob o governo e o regime fascista, mas apenas como classe-apoio, isto é, uma classe que, na definição de Poulantzas, serve de base a um regime político determinado por razões ideológicas e sem ter, necessariamente, seus interesses contemplados pelo governo (Poulantzas, 1968) - aliás, ao contrário, o que os estudos sobre o fascismo original mostram é que a pequena burguesia foi a primeira vítima da política econômica fascista favorável ao grande capital (Poulantzas, 1970).

Advirta-se que a fração burguesa que coopta o fascismo e, graças a isso, instaura sua hegemonia não é a burguesia agrária. Esta, embora tenha sido pioneira no apoio ao fascismo e ao neofascismo, não está, numa sociedade capitalista industrial e urbanizada, em condições de assumir a hegemonia na sociedade e sequer no bloco no poder - refiro-me aos pro- 
prietários de terra, e não ao conjunto dos segmentos burgueses envolvidos no agronegócio em que, de resto, os fazendeiros ocupam posição subordinada. Quem coopta o fascismo em proveito de sua hegemonia política são outras frações burguesas que são distintas no fascismo e no neofascismo - afinal, repetimos, o fascismo se define pela forma de Estado (ditadura), pelo regime político (fascismo) e engloba o movimento e a ideologia que implantam e legitimam esse regime, e não pela composição ou hierarquia do bloco no poder. ${ }^{11}$

Pois bem, no fascismo original, foi o grande capital monopolista que cooptou o movimento fascista predominantemente pequeno-burguês para encerrar o período de hegemonia política do médio capital. Seguimos nesse ponto a análise de Poulantzas e de autores marxistas coevos do fascismo, como Palmiro Togliatti, Georgi Dimitroff e Daniel Guerrin, análise segundo a qual o capital monopolista, embora já predominasse na economia italiana e alemã pré-fascista, não tinha ainda conquistado a hegemonia política no interior do bloco no poder, isto é, não tinha logrado colocar seus interesses no centro das decisões de política econômica, externa e social do Estado. Veio a conquistá-la e, diferentemente do que ocorreu em outros países centrais, como os Estados Unidos ou a Inglaterra, apenas quando da implantação da ditadura fascista. No neofascismo brasileiro, quem cooptou o movimento neনิ ofascista predominantemente de classe média $\sigma_{\text {S. }}$ foi o grande capital internacional e a fração da

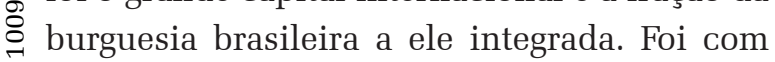
¿ै base nesse movimento que esses dois setores 今ึ burgueses recuperaram a hegemonia que ti-

. ${ }^{11}$ Atílio Boron entende, diferentemente do que acabamos . de afirmar, que o fascismo se caracterizaria pelo fato de ๓ representar a hegemonia no bloco no poder de uma bur-

$\triangleright$ guesia nacional imperialista. Ele se baseia na análise do

i fascismo original e deduz dessa tese que seria um "grave ¿ erro" caracterizar como fascista o governo Bolsonaro, ins. serido numa era em que a burguesia nacional seria "peça స de museu". Criticamos essa tese argumentando que, de um lado, tal como ocorre com a democracia burguesa ou

a ditadura militar, o fascismo é um regime político e per-

J mite, ainda que dentro de certos limites, a formação de di-

ferentes blocos no poder com diferentes frações burguesas

hegemônicas e, de outro lado, que uma mesma fração bur-

guesa pode exercer sua hegemonia em diferentes regimes 3 (Boito Junior, 2019). nham perdido durante os governos encabeçados pelo PT - fundamentaremos mais à frente essas afirmações. O fato é que a dinâmica de nascimento desde abaixo e cooptação pelo alto prevaleceu tanto no fascismo original quanto no neofascismo brasileiro. A herança dessa dinâmica é ambígua: ela fornece uma base de massa para o mandatário - Mussolini, Hitler, Bolsonaro -, mas pode criar dificuldades para a implementação da política burguesa pelo governo fascista, como já mostraram os conflitos do governo Bolsonaro com o movimento dos caminhoneiros.

O fascismo original surgiu no século XX nos países centrais. Foi um movimento reacionário de massa predominantemente pequeno-burguês, voltado contra o movimento operário socialista e comunista, que mobilizou uma crítica conservadora, típica do pequeno proprietário, à economia capitalista e à política parlamentar e chegou ao governo cooptado pelo grande capital. O neofascismo surgiu no século XXI e, no caso brasileiro, na semiperiferia do sistema imperialista. ${ }^{12}$ É um movimento reacionário de massa predominantemente de alta classe média, e não pequeno-burguês; voltado contra o movimento democrático e popular, e não contra um movimento socialista e comunista de massa que não existe no Brasil atual; mobiliza uma crítica conservadora, de classe média, à corrupção e à política democrática, e chegou ao governo cooptado pelo capital financeiro internacional e pela fração da burguesia brasileira a ele integrada, e não por uma burguesia nacional expansionista que, de fato, não existe no Brasil. Ambos os movimentos prestam serviços a frações da burguesia, mas sem se deixar reduzir a instrumentos passivos que essas frações manipulariam ao seu bel prazer.

\footnotetext{
${ }^{12}$ Como advertimos no início deste texto, segundo o conceito que estamos elaborando, nem todo governo ou movimento de extrema-direita da atualidade pode ser caracterizado como neofascista. Para sê-lo, ele tem de representar uma reação com base de massa a um movimento ou governo de esquerda ou de centro-esquerda.
} 


\section{PARALELO ENTRE A CRISE PO- LÍTICA GERADORA DO NEOFAS- CISMO E AQUELA DO FASCISMO ORIGINAL}

O fascismo não brota apenas de uma crise conjuntural. Os estudiosos do fascismo original destacaram o processo de unificação tardio da Alemanha e da Itália, a posição intermediária desses países na cadeia imperialista, o peso de instituições e ideologia feudais remanescentes - a Prússia, o Mezzogiorno como elementos da história de longa duração que favoreceram o surgimento do fascismo. No Brasil, o longo e recente passado escravista, as mudanças políticas efetuadas pelo alto, como em 1930 e 1985, a instabilidade do regime democrático, a tradição do pensamento autoritário e a significativa presença da classe média como força social distinta - ora progressista, ora conservadora - na história política nacional concorreram, de maneiras variadas, para a formação do quadro histórico que favoreceu o surgimento do neofascismo. Gramsci destaca um elemento social de longa duração e importante para a explicação do surgimento do fascismo na Itália: a violência entranhada na sociedade italiana. Como hipótese, podemos supor que seja mais fácil surgir e crescer um movimento que elege a violência como objeto de culto numa sociedade que já pratica regularmente a violência em forma extremada. ${ }^{13}$ Nossa análise, contudo, se restringirá à conjuntura na qual o neofascismo se originou.

Se partirmos da caracterização sintética que Poulantzas faz da crise política que gerou o fascismo original, veremos que o modelo que ele apresenta pode se aplicar à crise política da qual se originou o neofascismo no Brasil,

${ }^{13}$ GRAMSCI, A. Forze elementari. In: Antonio Gramsci, Sul fascismo. Organizado por Enzo Santarelli. Editori Riuniti. 2012. p. 105-107. Gramsci descreve um cenário que permite pensar em semelhanças entre o Brasil de hoje e a Itália do início do século passado. Gramsci destaca, com exemplos ilustrativos, a prática corrente do homicídio na Itália de então, os massacres de população pobre, as formas humilhantes de controle dos trabalhadores por seus patróes e a violência privada dos proprietários de terra. Ver particularmente a página 106. a despeito das inevitáveis particularidades de uma e de outra. Lá, a crise política levou, tanto na Itália quanto na Alemanha, à implantação de governos sob controle do partido fascista, mas em composição com partidos burgueses, e, em seguida, à implantação de uma ditadura fascista, passagem que se deu de modo gradativo e relativamente prolongado no primeiro país e de modo concentrado no tempo e rápido no segundo. Aqui, o que temos até o presente é um governo com predomínio fascista que faz ameaças e toma medidas contra a democracia. Tais diferenças de resultados devem encontrar raízes nas especificidades de tais crises.

Do mesmo modo que fizemos quando caracterizamos o neofascismo, diremos que, mudando o que deve ser mudado, mas permanecendo dentro dos limites de uma matriz conceitual que é comum a ambos os fenômenos comparados, é defensável sustentar que, entre, de um lado, a crise política que deu origem ao fascismo original e, de outro, a crise política que deu origem ao neofascismo no Brasil, entre uma e outra, predomina a semelhança. O leitor poderá estranhar tal afirmação. Na segunda década do século XX, embora já tivéssemos um capitalismo financeiro e internacionalizado, era outra, então, a etapa desse sistema e do sistema imperialista internacional. Ademais, a classe operária encontrava-se organizada nos partidos socialista e comunista, e a Europa burguesa enfrentava a ameaça representada pela Revolução Russa de 1917. Porém, do mesmo modo que historiadores e economistas apontam a semelhança de aspectos fundamentais da crise econômica de 1929 com aspectos da crise econômica de 2008 - afinal ambas são crises da mesma economia capitalista em períodos de semelhante predomínio financeiro e gestadas nos países centrais -, assim também as citadas crises políticas apresentam regularidades como ocorridas no contexto de um mesmo tipo de Estado, o capitalista, que se desenvolveram no interior do processo político que é próprio da sociedade capitalista, que articula de maneira inédita 
na história os conflitos entre frações da classe dominante com a luta das classes populares, e são crises que se inserem em instituições e mobilizam instrumentos políticos originais desse mesmo tipo de sociedade - como é, justamente, o caso do partido de massa que surge apenas no capitalismo e organizando, pela primeira vez na história de modo estável e legal, a classe trabalhadora fundamental de uma sociedade de classes. Enfim, estamos adotando uma tese e uma suposição: a) as crises políticas na sociedade capitalista apresentam particularidades diante de suas congêneres em sociedades escravistas e feudais; e b) estamos supondo que essas crises podem variar, mas apenas dentro de certos limites.

Nicos Poulantzas não é o primeiro autor marxista a conceber a ideia de que o fascismo nasce de um tipo particular de crise política. Contudo é ele, salvo engano, o primeiro a procurar retirar dessa ideia todas as suas consequências. Ele sustenta que os diferentes regimes políticos da forma de Estado capitalista de exceção - fascismo, ditadura militar, bonapartismo - provêm de diferentes tipos de crise política. Ao proceder assim, rompe com o economicismo e o historicismo que marcam algumas tradições marxistas: rompe com a ideia de que somente a economia tem uma dinâmica necessária que se impõe às intenções dos agentes enquanto a política seria o campo de exercício da liberdade, e rompe também $\vec{\delta}$ com a ideia correlata de que, na política, tudo is se explicaria pelas circunstâncias específicas ¿े de cada conjuntura, circunstâncias essas que, \&े de tão variadas, seriam refratárias à construసิ ção de modelos explicativos. Supõe, portanto, $\dot{2}$ a possibilidade de tipificar o processo político ङ das sociedades capitalistas de modo a explicar $\overrightarrow{\text { e }}$ e, em certa medida, prever a transição de um Estado democrático para um Estado ditatorial e, ademais, para este ou aquele tipo de ditadura - fascista, militar, bonapartista.

Desta forma, para chegar ao problema da crise política, devemos fazer a seguinte pergunta: podemos identificar as características gerais de uma crise po- lítica distinta da situação revolucionária em sentido estrito, uma crise que determina uma forma de Estado e formas de regimes verdadeiramente específicos? [...] podemos determinar, no quadro geral da crise política, espécies diferentes e particulares de crise, cada uma conduzindo a formas de regime de exceção - bonapartismo, ditaduras militares, fascismo - específicas da forma de estado de exceção? (Poulantzas, 1970, p. 60, tradução nossa).

Em Fascismo e ditadura, Poulantzas não logra, no nosso modo de ver, entregar por completo o que prometeu sobre essa questão. Ele apresenta uma caracterização muito rica da crise política que permitiu a ascensão do fascismo ao poder na Itália, em 1922, e na Alemanha, em 1933. Evidencia que, a despeito das especificidades de uma e de outra, o modelo de crise é o mesmo, mas não esclarece suficientemente porque o tipo de crise que ele apresenta não poderia levar, por exemplo, a uma ditadura militar - possibilidade que, de resto, esteve presente tanto na Itália quanto na República de Weimar. Localizamos a origem dessa lacuna no seguinte ponto: parece-nos que faltou ao trabalho de Poulantzas uma análise específica da dinâmica da crise política que levou ao fascismo. Como os diferentes elementos que Poulantzas utiliza para caracterizar a crise política que deu origem ao fascismo agem uns sobre os outros? Como essa ação incide sobre a evolução da crise? Como essa evolução propicia viragens nas posições das forças em presença? Essas questões, se bem respondidas, permitiriam, nós acreditamos, avançar no caminho aberto por Poulantzas em seu livro.

Poulantzas aponta muitos aspectos e dimensões para caracterizar tal crise política. Ei-los aqui minuciados:

a) acirramento dos conflitos no interior do bloco no poder - conflito entre o médio e o grande capital, entre a burguesia agrária e o grande capital, entre os proprietários semifeudais da terra e o grande capital; b) crise da representação partidária das classes dominantes: rompimento dos laços de representação partidária entre representantes e representados, e declínio eleitoral dos partidos burgueses tradicionais;

c) instabilidade política e incapacidade hegemôni- 
ca das classes e frações dominantes, fragmentação das organizações políticas burguesas, sendo que a solução não fascista da crise exigiria a fusão dessas organizações num partido único da burguesia;

d) os partidos políticos tradicionais da burguesia não adotam o fascismo, tentam até mesmo, e ainda que timidamente, resistir à sua ascensão;

e) ativismo político e fortalecimento da burocracia civil e militar do Estado - Forças Armadas, Polícia, tribunais, administração - em detrimento dos partidos políticos;

f) conflito entre ramos e instituições do Estado vinculado aos conflitos de classe e crise institucional;

g) distorção característica entre o "poder formal” e o "poder real" caracterizando a crise política;

h) impossibilidade de qualquer fração da classe dominante estabelecer ou manter sua hegemonia nos quadros do regime democrático;

i) multiplicam-se os ataques aos partidos políticos e à política parlamentar;

j) série de derrotas e situação política defensiva do movimento operário;

k) ofensiva da burguesia e, particularmente, do grande capital contra o movimento operário;

l) constituição da pequena burguesia como força social distinta;

m) crise ideológica generalizada, tanto das ideologias da classe dominante quanto das ideologias das classes dominadas - inclusive na ideologia socialista.

Como dissemos, essa lista guarda notória semelhança com a situação brasileira que deu origem ao governo Bolsonaro. Indicaremos isso a seguir. Agora queremos apontar que tais elementos caracterizadores da crise são apresentados de modo abundante e descritivo, e sua dinâmica, como também já dissemos, não é analisada com o devido destaque por Poulantzas. Vamos reter o essencial dessa longa lista e tratar de pensar a relação entre os elementos e a dinâmica da crise, tomando para análise o caso brasileiro.

Observemos a lista. Em primeiro lugar, do ponto 1 ao ponto 9 , trata-se de elementos referentes à burguesia, aos ramos e instituições do aparelho de Estado e aos partidos políticos burgueses. Em segundo lugar, os pontos 9, 10, 11 e 12 referem-se ao movimento operário e à pequena burguesia e, por último, o ponto 13 diz respeito à conjuntura de crise ideológica generalizada. Nos nove pontos referentes à classe dominante, aos seus partidos e ao Estado, há, segundo nos parece, elementos de circunstância e desdobramentos que podem ser descartados para uma caracterização geral da crise política característica do nascimento do fascismo. Reteríamos, então, os três elementos seguintes: acirramento dos conflitos no interior do bloco no poder, crise da representação partidária das classes dominantes e ativismo político e fortalecimento da burocracia civil - aí incluído o judiciário - e militar do Estado. Em seguida, é importante reter, no campo das classes populares, a série de derrotas e a situação defensiva do movimento operário, bem como a novidade que foi a constituição da pequena burguesia como força social distinta e, por último, a crise ideológica generalizada. Ficamos, assim, com seis elementos caracterizadores da crise política que leva ao fascismo:

a) acirramento dos conflitos no interior do bloco no poder;

b) crise da representação partidária das classes dominantes;

c) ativismo político da burocracia civil e militar provocando crise institucional;

d) série de derrotas e situação defensiva do movimento operário;

e) constituição da pequena burguesia como força social distinta; e

f) a crise ideológica generalizada.

Quanto à dinâmica da crise política, consideramos importante detectar algumas interações e encadeamentos entre os elementos citados e a evolução política que proporcionam. É o acirramento dos conflitos no interior do bloco no poder que desencadeia a crise política - o movimento operário encontra-se organizado, ativo, mas derrotado e na defensiva. Esse acirramento somado à crise de representação partidária da burguesia agrava e prolonga a crise. Os partidos burgueses perdem apoio eleitoral, e a burguesia e suas frações não se reconhecem mais em suas propostas programáticas. Estão impossibilitadas de desmobilizar o movimento operário e se tornam disponíveis 
para a adoção de soluções que até então seriam rechaçadas como aventureiras inclusive para o rompimento com o jogo democrático. O movimento operário, embora impossibilitado de apresentar uma saída própria para a crise política devido às derrotas sofridas e à sua situação defensiva, permanece suficientemente organizado e ativo para resistir ao aprofundamento da exploração pleiteado pelo grande capital. Essa fração da burguesia não aceita a política de conciliação que os governos do médio capital - Giolitti (1920-1921) na Itália e Brüning (1930-1932) na Alemanha - propõem à socialdemocracia. ${ }^{14}$ A pequena burguesia, organizando-se, por intermédio do movimento e do partido fascista, como força social distinta, assume o combate ao movimento operário, que também era o objetivo do grande capital, mas revela notável incapacidade hegemônica: não apresenta uma plataforma própria e coerente para a política econômica, externa e social. Sua organização desencadeia ações violentas contra as organizações operárias e se destaca por uma pronunciada ideologização da ação política como resposta aos ensaios, para ela ameaçadores, de revoluções operárias na Itália e na Alemanha e diante da vitória da Revolução Russa. A carência de partidos políticos representativos da burguesia torna necessária e a incapacidade hegemônica da pequena burguesia torna viável a tática do capital monopolista de se apropriar politicamente do movimento fascista pequeno-burస్రิ guês para instaurar sua hegemonia política.

N $\quad$ Esse tipo de crise política e essa dinâmica são, mudando o que deve ser mudado, semelhantes àquilo que temos visto na política brasileira nos anos recentes. Vamos analisar a ¿. seguir como cada um dos pontos e também a கં dinâmica desse tipo de crise se apresentam no

$\vec{i}$ Brasil. Começaremos pelo exame dos conflitos no interior das classes dominantes.

${ }^{14}$ Poulantzas (1970) apresenta fatos e argumentos convinI. centes para defender a tese da existência de uma relação política preferencial dos governos Giolitti e Brüning com o médio capital e para evidenciar a política de conciliação desses mesmos governos com o movimento operário, bem como para mostrar a oposição do grande capital a ambos (Poulantzas, 1970).
Em pesquisas anteriores, chegamos à conclusão de que o principal conflito no interior da burguesia brasileira tem sido o conflito que opõe, ainda que moderadamente, as grandes empresas nacionais que são a base do que denominei "grande burguesia interna", ao capital estrangeiro e à burguesia a ele associada (Boito Junior, 2018). Convém fornecer alguma indicação sobre o que estou denominando capital estrangeiro e burguesia associada.

O capital estrangeiro é heterogêneo e mantém relações variadas com a economia brasileira (Farias, 2018). Temos o capital estrangeiro externo, que entretém com a economia brasileira relação meramente comercial ou financeira - indústria automobilística sem planta instalada no Brasil, capital de empréstimo para empresas brasileiras ou implantadas no Brasil etc. Temos também o capital estrangeiro internalizado - plantas industriais pertencentes a empresas multinacionais e implantadas no Brasil, capital financeiro possuidor de bancos comerciais, de investimentos ou seguradoras com filiais no Brasil, capital financeiro presente no mercado de ações e de títulos da dívida pública etc. O capital estrangeiro, externo ou internalizado, pode, como se vê nos exemplos citados, atuar em vários setores da economia.

É complexo analisar a ação política desses segmentos burgueses. Eles não proclamam abertamente seus interesses e preferem agir nos corredores da burocracia de Estado, não de maneira pública na cena política (Guilmo, 2019). Possuem, contudo, algumas associações conhecidas, como a Câmara do Comércio Brasil-Estados Unidos (Amcham), o Instituto Brasileiro do Petróleo, a Associação Brasileira de Bancos Internacionais, a Associação Internacional de Mercado de Capitais, Associação Brasileira das Entidades dos Mercados Financeiro e de Capitais e outras (Guilmo, 2019; Valle, 2019). O Instituto Brasileiro do Petróleo, que sempre abrigou em sua diretoria integrantes do estafe das grandes petroleiras estrangeiras, representa os interesses dessas últimas. Resistiu à política para o petróleo dos governos encabe- 
çados pelo PT e, uma vez empossado Michel Temer, passou a ter livre trânsito no Palácio do Planalto e foi voz importante na mudança da política para o setor (Narciso, 2019). As seguradoras e os bancos estrangeiros presentes no Brasil foram ouvidos sobre o projeto de reforma da previdência do governo Temer antes que tal governo ouvisse as centrais sindicais. A imprensa publicou a agenda do Ministério da Fazenda e da Previdência, da qual constava uma sequência de reuniões, que tinham por pauta a reforma da previdência, entre o ministro Henrique Meirelles e cerca de dez instituições financeiras internacionais. O então presidente Michel Temer compareceu pessoalmente a um encontro de investidores internacionais reunidos pelo Banco JP Morgan, em São Paulo, para lhes expor as supostas virtudes da PEC do congelamento dos gastos públicos e do projeto de reforma da previdência social (Boehm, 2016). O Departamento de Justiça dos Estados Unidos ofereceu, como se tornou público, inicialmente graças aos documentos revelados pelo site WikiLeaks e, posteriormente, por reportagens da grande imprensa, vários cursos para a formação de recursos humanos para a Operação Lava Jato, que liquidou o monopólio das grandes construtoras nacionais no mercado interno de obras públicas - e o Programa de Aceleração do Crescimento (PAC) tinha tornado o mercado brasileiro de obras públicas maior que os mercados da Argentina e da Índia somados.

Se considerarmos os diferentes segmentos do capital estrangeiro vinculados à economia brasileira, internalizados ou não, podemos constatar que as associações e os Estados nacionais a eles ligados pressionam, no geral, pela implantação de uma política neoliberal extremada: abertura comercial, desregulamentação financeira, privatizações, superávit primário, redução dos direitos trabalhistas e sociais. Até a eleição de Bolsonaro, era o PSDB que vocalizava na cena política essa plataforma do capital internacional e da burguesia associada. A burguesia interna, por seu lado, faz oposição seletiva a um ou outro aspecto dessa plataforma e, quando o faz, entra em conflito com o capital internacional - como indicaremos mais à frente a título de ilustração.

A ideia da existência de um conflito entre, de um lado, o que estou denominando grande burguesia interna e, de outro, o capital internacional e a grande burguesia associada, é polêmica e tem propiciado, por parte dos críticos dessa tese, um uso anacrônico e deslocado da bibliografia sobre a questão da inexistência de uma burguesia nacional no Brasil. Anacrônico porque usa, para analisar o Brasil de hoje, uma bibliografia produzida nas décadas de 1960 e 1970 que discorre sobre aquele período, e não sobre o Brasil atual; deslocado porque, para saber se existe ou não no Brasil atual conflito entre o capital nacional e o capital estrangeiro, recorre a uma bibliografia que discute algo diferente e muito mais profundo, qual seja a questão de saber se existiria no Brasil uma burguesia nacional anti-imperialista, que era o tema em debate nas décadas de 1960 e 1970. Por isso iniciaremos o exame dos conflitos no interior do bloco no poder realizando uma breve digressão.

A ditadura militar brasileira logrou unir numa aliança estável a grande burguesia interna brasileira e o capital internacional. Essa aliança contrasta com o que se passava no bloco no poder no período 1930-1964. Até então, a burocracia de Estado, agindo como força social distinta, havia empolgado um programa industrializante, contando com o apoio hesitante da burguesia industrial interna e dos trabalhadores urbanos para contornar ou vencer interesses imperialistas que, durante esse período, apresentavam obstáculos variados ao avanço da industrialização brasileira (Farias, 2018). Tais obstáculos foram sendo desmontados pelo Estado nacional brasileiro e, na medida em que avançava a industrialização, foram também sendo retirados pelo próprio imperialismo que, gradativamente, foi aderindo ao programa industrializante. O programa desenvolvimentista da ditadura militar, ao amputar a perna populista e popular daquela 
que foi a primeira fase do desenvolvimentismo clássico, logrou atender, ao mesmo tempo, aos interesses da grande burguesia interna e do capital estrangeiro que, na passagem da década de 1950 para a década de 1960, aderira progressivamente ao processo de industrialização dependente do Brasil e em outros países da América Latina.

Essa aliança foi analisada em ensaios clássicos da historiografia, da sociologia e da ciência política brasileira. Basta pensar nos textos de Caio Prado Jr. (1966), Fernando Henrique Cardoso e Faletto (1970), Florestan Fernandes (1973), Peter Evans (1980) e outros. Cardoso designou a situação da década de 1960 e 1970 com o conceito de nova dependência, por contraste com a antiga forma de dependência, vigente nas três primeiras décadas do século XX e que se baseava no capital de empréstimo e na especialização da periferia na produção de bens primários. Característica fundamental da nova dependência era o investimento estrangeiro industrializante, denominada internacionalização do mercado interno. Com a política desenvolvimentista da ditadura militar e essa nova postura do imperialismo, dependência e desenvolvimento (do capitalismo) na América Latina se tornaram compatíveis, e não mais excludentes como imaginava até então - e não sem motivo, acrescentamos nós - grande parte do pensamento crítico brasileiro e dos intelectuais comunistas. Caio Prado Jr. (1966), em seu ন্ ensaio, ao argumentar contra a tese da exis$\stackrel{N}{\circ}$ tência de uma burguesia nacional que poderia participar da primeira etapa - anti-imperialista Q e antifeudal - da revolução brasileira, pergun今ึ tava a seus adversários teóricos e políticos: por $\therefore$ qual motivo a burguesia brasileira se voltaria ले contra o imperialismo se o capital estrangeiro estava, ao abrir plantas novas e criar ramos industriais inteiros no Brasil, como a moderna indústria farmacêutica, possibilitando oportunidades de investimentos e vendas jamais vistas pela burguesia brasileira? Caio Prado chega a falar em aspecto progressista que o imperialismo tinha então assumido. Peter Evans
(1980) examina com riqueza de detalhes essas oportunidades de investimento para o capital nacional em diferentes ramos da economia oportunidades que variavam de um ramo para outro, é verdade - e corrobora a tese de Cardoso e Faletto (1970), de Caio Prado (1966) e de Florestan (1973). Formara-se uma "tríplice aliança” entre capital estatal, capital privado nacional e capital estrangeiro.

O avanço do modelo capitalista neoliberal minou aquela aliança. Com esse modelo, veio uma novíssima forma de dependência que revigorou a dimensão financeira na relação entre o centro imperialista e a periferia dependente e pressionou e ainda pressiona para que seja revigorada também a função primário-exportadora da economia latino-americana na divisão imperialista do trabalho, fazendo recuar o processo de industrialização periférica. $\mathrm{O}$ economista Samir Amin qualificou essa novíssima dependência como uma relação de bombeamento ou de sucção sem contrapartida (Amin, 2002; Dumenil; Lévy, 2004). A ideia é que a nova dependência teria estimulado, ainda que dentro dos limites da dependência, a modernização capitalista da periferia, ao passo que a novíssima dependência não teria nada a oferecer a essa mesma periferia como compensação pela dominação e exploração imperialista.

A conclusão a que se deve chegar para o tema do qual nos ocupamos é a seguinte: na novíssima forma de dependência, redefiniram-se os interesses e a posição dos diferentes segmentos da burguesia brasileira. É por isso que é anacrônico citar as obras dos autores que escreveram tratando do período desenvolvimentista, obras datadas, como se elas fossem suficientes para esclarecer a posição atual da burguesia brasileira. Em debates públicos, citam-se as teses de Caio Prado, Cardoso e Faletto, Florestan e outros sobre a aliança sólida da burguesia brasileira com o capital estrangeiro como se ainda estivéssemos no período desenvolvimentista. Esquecem-se, no entanto, de citar o argumento com o qual tais autores sustentavam essa tese e sem o qual tal tese não faz 
sentido: o argumento se referia ao fato de o imperialismo agir, na época, como mola propulsora do desenvolvimento capitalista do país. Ora, é preciso ter em mente que o capitalismo brasileiro deixou para trás a época do chamado desenvolvimento dependente ou associado, no qual a economia cresceu a uma taxa média superior a $5 \%$ ao ano ao longo de meio século, e ingressou numa época de crescimento baixo e estagnação. A grande burguesia interna que ascendera à hegemonia política, juntamente com o grande capital internacional graças à ditadura militar, marginalizando no interior do bloco no poder os interesses do médio capital, viu crescer seus conflitos com seu antigo aliado. Não tivemos a formação de uma burguesia nacional anti-imperialista tardia no Brasil, mas tampouco assistimos à integração completa do conjunto da burguesia brasileira ao capital internacional. A partir da implantação do modelo capitalista neoliberal e da novíssima dependência que lhe corresponde, o conflito entre o médio e o grande capital, que fora dominante até então no bloco no poder, foi substituído nesse posto pelo conflito entre a grande burguesia interna e a dobradinha formada pelo capital internacional e a fração da burguesia brasileira a ele integrada.

Durante as três últimas décadas da história política brasileira, foi esse o conflito principal no seio do bloco no poder. Os conflitos entre o médio e o grande capital, entre os segmentos bancário e produtivo e outros continuaram ativos, mas o conflito principal, no nosso entendimento, é o que citamos. Esse conflito não exclui a unidade. A grande burguesia interna não é uma burguesia nacional. Ela não faz nada para romper com o imperialismo e não tem interesse em tal rompimento. Mas, nos limites dessa unidade geral, existem conflitos variados entre os diferentes segmentos da burguesia interna - os bancos, a indústria, a agropecuária - e o capital estrangeiro, internalizado ou não, nos diferentes ramos da economia.

Para ilustrar, apresentemos um brevíssimo contraste entre, de um lado, alguns ele- mentos da política econômica dos governos FHC, Temer e Bolsonaro, todos eles representantes da hegemonia do capital internacional e da burguesia associada, e, de outro, a política econômica dos governos encabeçados pelo PT, que organizaram a hegemonia da grande burguesia interna. O que queremos indicar é que, em seus múltiplos e variados aspectos, a política neoliberal fere, para atender aos interesses do capital internacional e da fração da burguesia brasileira a ele integrada, os interesses de diferentes segmentos da grande burguesia interna e que a política neodesenvolvimentista dos governos encabeçados pelo PT fez exatamente o oposto, isto é, relegou a um plano secundário os interesses do capital internacional para atender a grande burguesia interna (Boito Junior, 2018). Os bancos resistem a políticas de internacionalização do mercado bancário brasileiro como aquelas implantadas por Fernando Henrique Cardoso e Pedro Malan em 1995, revertidas pelos governos encabeçados pelo PT e que voltam a ser cogitadas no Brasil atual; a indústria resiste à abertura comercial na amplitude exigida pelo capital internacional, foi contemplada com as políticas de conteúdo local nos governos do PT e volta, na atualidade, a perder essas reservas de mercado; a agropecuária resiste às políticas de equilíbrio fiscal que colidem com a política de empréstimo subsidiado, sucessivos perdões das dívidas dos fazendeiros junto aos bancos públicos e de preços mínimo garantidos para a produção agrícola; a construção pesada perdeu com a desativação do mercado de obras públicas nos governos FHC, teve seus interesses atendidos pelo PAC do segundo governo Lula e voltou a ser tratada a pão e água pela política de austeridade fiscal de Temer e Bolsonaro.

Voltando ao cerne do nosso problema, o conflito do capital internacional com a grande burguesia interna se agravou justamente na crise política de 2014-2018, e essa é, como vimos, a primeira característica de uma crise política que pode levar ao fascismo em qualquer de suas variantes. 
Serei breve nesse primeiro ponto e tomo a liberdade de remeter o leitor interessado em uma análise mais fundamentada do problema para o meu citado livro Reforma e crise política no Brasil. A crise política se iniciou devido a uma ofensiva política restauradora do capital internacional e da burguesia associada contra o governo Dilma, pois os governos encabeçados pelo PT representavam a hegemonia da grande burguesia interna no bloco no poder. Essa hegemonia foi obtida graças à estratégia dos governos encabeçados pelo PT de formar uma ampla frente política, que eu denomino neodesenvolvimentista, frente política essa que incorporou no plano das medidas de política social grande parte da baixa classe média, do operariado, do campesinato e, principalmente, dos trabalhadores da massa marginal. Os governos Cardoso tinham representado a hegemonia do capital internacional e da fração da burguesia a ele associada, tendo como base preferencial de apoio a classe média alta, mas também setores operários - basta lembrar a posição favorável da central Força Sindical a políticas neoliberais. Como já indicamos, Cardoso radicalizou a abertura comercial, reduzindo à metade as tarifas aduaneiras que já tinham sido reduzidas pelo governo Collor; juntamente com Pedro Malan, iniciou de modo acelerado uma política de internacionalização do mercado bancário; reduziu drasticamente o crédito agrícola subsidiado e congelou o mercado de obras públicas. Essas సิ medidas, uma a uma, feriam interesses de dife-
Enquanto houve crescimento econômico no período dos governos encabeçados pelo PT, o capital internacional permaneceu na defensiva. Os candidatos presidenciais do PSDB - que funcionou entre 1995 e 2015 como o partido político do capital internacional e da burguesia associada, e não da classe média que é apenas sua base social - procuravam, inclusive, esconder na campanha eleitoral sua condição de herdeiros de Fernando Henrique Cardoso. A situação começou a mudar em decorrência da política do primeiro governo Dilma, que representou uma tentativa de radicalizar o neodesenvolvimentismo petista, de aprofundar a integração do Brasil ao grupo dos Brics e em decorrência também da queda do crescimento econômico. Nessa nova situação, o capital internacional e a fração da burguesia brasileira a ele integrada - bem como o Estado norte-americano, conforme já atestam documentos tornados públicos - avaliaram que era necessário reagir e que seria possível vencer. Passaram, então, à ofensiva política (Boito Junior, 2018). Primeiro, apostaram na vitória eleitoral em 2014, chegaram perto de conquistá-la, mas perderam. Depois, assumiram a proposta do impeachment que nascera no movimento da alta classe média. Finalmente, ao longo do segundo semestre de 2015, lograram afastar parte da grande burguesia interna da base do governo Dilma. A burguesia interna também demonstrava interesse em retomar o programa de reformas trabalhista e previdenciária e, ademais, imaginou-se segura porque, com o impeachment, quem assumiria o governo seria o PMDB, e não o PSDB. O fato é que, com esse deslocamento de força, a frente política neodesenvolvimentista entrou em crise.

O conflito entre os de cima, que ensejou uma campanha eleitoral polarizada e politizadora em 2014, e a crescente insatisfação da alta classe média com a política social dos governos encabeçados pelo PT ensejaram o surgimento da segunda característica da crise política que pode originar o fascismo: a constituição de uma classe intermediária, no caso do neofas- 
cismo, a classe média, em força social distinta, reacionária e ativa. Foi após a eleição de 2014, polarizada entre dois campos políticos dirigidos, cada um deles, por uma das frações burguesas em luta, que a classe média e, particularmente, sua fração superior, organizou-se em força social distinta. Organizações e intelectuais desse segmento social tomaram a iniciativa de propor o impeachment de Dilma Rousseff e criaram movimentos novos e especialmente voltados para a luta pela deposição da presidente eleita. O PSDB, o partido da burguesia associada e do capital internacional, hesitou. Diante da perspectiva de mais quatro ou talvez doze anos de governos encabeçados pelo PT, posto que após o segundo mandato de Dilma o candidato do campo neodesenvolvimentista seria Lula da Silva, apostara na impugnação da vitória de Dilma Rousseff na justiça eleitoral. Perdeu e passou meses com uma linha hesitante, pois sua direção estava dividida sobre a proposta de impeachment que viera do movimento de classe média. José Serra era a favor de abraçar a proposta, Geraldo Alckmin era contrário e Fernando Henrique Cardoso balançava entre os dois - afirmava que a oposição deveria, sim, agitar a proposta do impeachment, mas apenas como ameaça (Singer, 2018). Um episódio significativo, que é sintoma da diferença entre, de um lado, o perfil social e a orientação política do PSDB e, de outro, o perfil e a orientação do movimento pelo impeachment, foi a expulsão dos principais dirigentes tucanos de uma manifestação pelo impeachment na Avenida Paulista - para a qual, de resto, sequer tinham sido convidados.

Por que o movimento da massa da alta classe média pela deposição de Dilma Rousseff pode ser considerado o embrião do movimento neofascista? Primeiro, a motivação do conjunto do movimento era reacionária. Ela expressava a revolta da alta classe média com a pequena ascensão das camadas de renda mais baixa, ascensão essa propiciada pela política econômica e social dos governos encabeçados pelo PT. E o movimento da alta classe média identificou no PT e na esquerda o inimigo a ser combatido e eliminado. As manifestações de rua, suas palavras de ordem, as referências grosseiras e agressivas aos adeptos da esquerda e da centro-esquerda, a ameaça e a agressão a seus militantes, dirigentes e intelectuais em locais públicos por bandos dessa extrema-direita atestam o que afirmamos. Em segundo lugar, porque o conjunto do movimento reacionário de classe média rompia com o jogo democrático, ao pleitear o impeachment sem sequer terem encontrado motivo que o fundamentasse e algumas de suas alas lutavam explicitamente pela implantação de uma ditadura - pediam a intervenção militar. Acrescente-se que as pesquisas de intenção de voto, bem como o mapa das apurações de 2018, evidenciam que a alta classe média votou na proporção de 8 ou 9 sobre dez no candidato que defendeu abertamente durante a sua campanha eleitoral a ditadura militar, a tortura, os torturadores, o machismo e a homofobia.

É certo que esse movimento não era e não é homogêneo. O Movimento Brasil Livre (MBL) assumiu pioneiramente a proposta do impeachment, enquanto o grupo Vem pra Rua chegou a tal posição mais tarde. Já sob o governo Bolsonaro, os dois grupos citados decidiram não participar da manifestação de 26 de maio de 2019 quando notaram a força das palavras de ordem que propunham o fechamento do Congresso Nacional e do Supremo Tribunal Federal. Porém ambos mobilizaram suas bases, um mês depois, em 30 de junho, para uma manifestação de apoio ao governo neofascista de Bolsonaro. Tudo isso parece indicar o que já afirmaram muitos observadores: há um núcleo duro do bolsonarismo, que nós estamos caracterizando como neofascista, que é a base militante de Bolsonaro e em torno do qual gravita uma periferia mais ampla de variados matizes de direita e extrema-direita.

Duas observações relacionadas ao elemento analisado: primeiro, a mobilização reacionária da classe média esteve vinculada ao surgimento do ativismo político da burocracia civil, mormente do Judiciário e da Polícia Fe- 
deral, e às crises institucionais daí derivadas; segundo, dizer que o neofascismo é um movimento da alta classe média não significa que não tenha obtido impacto popular. Sobre o ativismo político da burocracia de Estado, que é o terceiro elemento que analisamos da crise política que antecede o fascismo, é claro que estamos nos referindo à Operação Lava Jato, que envolveu grande parte do "sistema de justiça" - contou com a cobertura passiva e ativa do STF, dos tribunais superiores e regionais e da PGR. Os delegados da Polícia Federal, os procuradores, juízes, desembargadores e ministros do STF são, ao mesmo tempo, parte integrante da alta classe média -seus salários altíssimos e suas condições de trabalho privilegiadas os colocam, para ser mais preciso, no topo dessa fração de classe - e também funcionários do aparelho repressivo do Estado, responsáveis pela manutenção da ordem capitalista. Esses dois pertencimentos sociais concorreram para a adesão ativa desses burocratas ao neofascismo ou para uma atitude conivente diante desse movimento. Na crise que precedeu a implantação do fascismo na Itália e na Alemanha, o aparelho judiciário também desempenhou um importante papel político, acobertando os crimes dos bandos fascistas e condenando unilateralmente as ações de autodefesa de socialistas e comunistas (Shirer, 2017). Na Alemanha, já no período pré-fascista, o parlamento foi esvaziado com a implantaస్ ção da prática de o primeiro ministro governar o. por decreto; no Brasil, o Executivo Federal e o Congresso foram cercados, ao longo da crise, velo Judiciário e pelas Forças Armadas. $\checkmark$ movimento da alta classe média foi, como é saले bido, engrossado, durante a campanha eleitoral

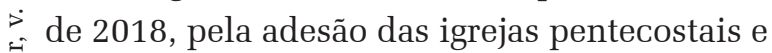
neopentecostais à candidatura neofascista de Bolsonaro. Essa adesão permitiu - e, ao que parece, fundamentalmente devido aos valores patriarcais, machistas e homofóbicos vigentes na base popular dessas igrejas - a penetração ainda que tardia da candidatura de Bolsonaro no meio popular. ${ }^{15}$ Ele escondeu seu programa neoliberal extremado desses trabalhadores. Porém deve-se notar que, assim como na Alemanha e na Itália os partidos socialistas e comunistas retiveram, enquanto houve eleições livres, a maioria eleitoral junto ao operariado, assim também no Brasil, Lula e o PT retiveram a hegemonia eleitoral entre os trabalhadores da massa marginal, como evidenciou a vitória de Fernando Haddad nos estados nordestinos na eleição presidencial de 2018. O neodesenvolvimentismo entrou em crise, mas o lulismo, não. A política econômica e social que procurava estimular o crescimento econômico e reduzir a pobreza por intermédio da intervenção do Estado perdeu sustentação, não só devido à ofensiva política restauradora do campo neoliberal ortodoxo, como também pela desagregação da frente política neodesenvolvimentista que sustentava tal política. Contudo o lulismo em seu sentido estrito, isto é, a relação neopopulista, ao mesmo tempo progressista e personalizada, de Lula da Silva com os trabalhadores da massa marginal, continua vivo e forte.

O quarto elemento da crise política que dá origem ao fascismo também está claramente presente na crise política brasileira. A classe operária e demais classes populares, assim como o campo democrático, sofreram sucessivas derrotas de 2014 em diante e se encontram desde então claramente na defensiva política. Verificou-se ainda uma crise ideológica do campo neodesenvolvimentista. O crescimento estava em queda, e o governo Dilma decidira aplicar um ajuste fiscal pesado, além de implantar ou anunciar medidas caras ao grande capital e antipopulares. A ofensiva ideológica do neoliberalismo completou o quadro. Passou-se a discutir o que foi chamado de esgotamento do programa neodesenvolvimentista. O governo Dilma deu o primeiro passo à direita $\mathrm{e}$

${ }^{15}$ Segundo a última pesquisa de intenção de voto realizada antes do segundo turno pelo instituto Datafolha, enquanto Bolsonaro e Haddad estavam praticamente empatados no eleitorado católico, na população evangélica Bolsonaro obtinha vantagem de 11 milhões de votos, montante um pouco superior à vantagem que Bolsonaro obteve no segundo turno da eleição (Alves, 2018). 
foi sucedido pelo governo Temer, que foi muito mais longe, representando uma mudança de qualidade. O governo que, no Brasil, antecedeu a implantação do governo neofascista já era, do mesmo modo que ocorreu com o fascismo original, um governo conservador. Isto é, nem o fascismo, nem o neofascismo surgem e, ao contrário do que ocorreu com as ditaduras militares no Cone Sul da América Latina, como resposta direta e imediata a governos populares ou reformistas.

Dissemos, retomando a expressão de Poulantzas, uma série de derrotas: abandono do programa neodesenvolvimentista por Dilma em 2015 no seu segundo mandato e negando tudo o que dissera na campanha eleitoral; derrota acachapante na votação do impeachment em abril de 2016; aprovação da PEC que congela os investimentos sociais em dezembro de 2016; aprovação final da Reforma Trabalhista em julho de 2017; condenação e prisão de Lula da Silva em abril de 2018, num processo claramente persecutório; impugnação da candidatura Lula e vitória de Jair Bolsonaro na eleição de 2018. Nessas derrotas, a mobilização operária e popular foi muito frágil. As manifestações neofascistas pela deposição de Dilma e pela prisão de Lula foram bem maiores que as manifestações em defesa dos trabalhadores, da democracia e dessas lideranças políticas. Era como se, no Brasil, a classe média abastada compusesse a maioria da população.

É certo que houve e há luta. A greve geral de protesto de um dia de duração contra a Reforma da Previdência em 28 de abril de 2017 foi um movimento muito bem-sucedido. Foram também realizadas duas grandes e bem-sucedidas manifestações de protesto de estudantes, professores e do pessoal da Educação, em maio de 2019, contra o corte de verbas promovido pelo governo Bolsonaro. Mas o corte de verba se manteve e está sendo aprofundado com o projeto da reforma neoliberal das universidades. A fragilidade maior é do movimento sindical. Outras greves ou dias nacionais de luta, além da greve de 28 de abril, foram malsuce- didos. Essas greves e protestos têm dependido em grande medida de pequenas organizações do movimento popular, vinculadas aos trabalhadores da massa marginal, que praticam o trancamento de rodovias e vias urbanas. De resto, a capacidade de resposta do movimento sindical à conjuntura é mesmo pequena. As greves gerais ou dias nacionais de luta precisam ser marcados com cerca de dois meses de antecedência, para contornar a relutância das centrais sindicais pelegas e para compensar a baixa capacidade de mobilização decorrente da distância entre a cúpula burocrática e a base sindical. Criou-se uma situação extravagante tanto no caso da luta contra a reforma trabalhista do governo Temer quanto no caso da luta contra a reforma da previdência do governo Bolsonaro. A data da greve, tendo de ser definida com tanta antecedência, precisou se basear em projeções incertas sobre o prazo para a tramitação das reformas de tal modo que, quando chegou o dia marcado para os trabalhadores cruzarem os braços, as votações das reformas pelo Legislativo já tinham ocorrido.

Ofensiva restauradora do campo neoliberal extremado, constituição de um movimento reacionário de classe média e derrotas e defensiva do movimento democrático e popular somaram-se à crise das instituições democráticas e de representação dos partidos burgueses para criar uma dinâmica que possibilitou a vitória do neofascismo no Brasil.

O partido político que tradicionalmente representava o campo neoliberal era o PSDB. Ele vinha numa trajetória eleitoral descendente. Sua boa performance na eleição presidencial de 2014 foi, na verdade uma reação passageira. Em 2018, nem esse nem qualquer outro partido burguês revelou viabilidade eleitoral. Como mostram reportagens da imprensa, principalmente do jornal Valor Econômico, o denominado "mercado" apoiava preferencialmente a candidatura Geraldo Alckmin. Na medida em que tal candidatura foi se revelando eleitoralmente inviável, o grande empresariado foi paulatinamente adotando a candidatura Bolso- 
naro que, repetimos, até 2017 era uma candidatura da alta classe média e que contava com o apoio de proprietários rurais. Os candidatos dos maiores e mais tradicionais partidos burgueses - o PSDB e o PMDB - somados ficaram com apenas 5,96\% dos votos válidos no primeiro turno da presidencial de 2018. A imprensa publicou reportagens que estampavam o grande medo que tomou conta do chamado mercado diante da possibilidade de vitória de uma candidatura dita populista que ameaçaria o programa de reformas neoliberais iniciado pelo governo Temer. Tratava-se de reconhecimento implícito de que os interesses do grande empresariado e a democracia tinham entrado em rota de colisão. A continuidade do programa econômico neoliberal, diferentemente do que ocorrera na década de 1990, parecia exigir soluções mais radicais e até temerárias, como o apoio à candidatura de um político de extrema-direita, defensor de regime ditatorial, sem base partidária e sem história que o credenciasse à Presidência da República. Mas a dinâmica da crise legitimou a opção dos grandes empresários. Os partidos políticos pisotearam a eleição de 2014, uma vara do judiciário assumiu a função de tribunal de exceção com jurisdição nacional, os militares diziam publicamente o que o STF podia ou não podia fazer: essa crise das instituições democráticas precedeu a opção do grande empresariado pela candidatura neofascista.

Além do cálculo eleitoral, havia também insatisfação da grande burguesia associada e do capital estrangeiro com aquilo que entendiam ser a moderação do neoliberalismo dos candidatos burgueses tradicionais. Alguns grandes empresários manifestaram na imprensa o desejo de reformas neoliberais mais profundas e ousadas, a passagem para um ultraliberalismo. Em um movimento simétrico e oposto ao realizado pelo campo democrático e popular, a grande burguesia também passou a procurar, se não um novo programa, uma dosagem mais forte do mesmo remédio que vinham aplicando. Ou seja, encontramos aqui um indicativo de crise ideológica generalizada dos dois programas políticos que até então polarizavam o processo político nacional - e esse é também, como vimos, um dos elementos característicos da crise política que antecede o fascismo. Um grande empresário afirmou ao jornal $V a-$ lor Econômico que Alckmin era um bom piloto de avião de passageiros, mas que "o Brasil" precisaria eleger para a presidência um piloto de avião de combate. A crise de representação partidária envolvia, portanto, a erosão dos laços entre representante e representado. Não foi apenas por pragmatismo eleitoral que os grandes empresários se aproximaram de Bolsonaro e Paulo Guedes, isto é, do neofascismo que lhes oferecia a política econômica ultraliberal.

Jair Bolsonaro percebeu, durante a campanha eleitoral, a proposta de cooptação de sua candidatura e decidiu anunciar o ultraliberal Paulo Guedes para o Ministério da Economia. Prometeu e está entregando o ultraliberalismo com nova rodada de abertura ao capital estrangeiro, com a política externa de alinhamento passivo com os Estados Unidos e com o corte de direitos trabalhistas e sociais. Porém, como é típico do fascismo, Bolsonaro e sua base social, embora estejam a serviço da grande burguesia, não aceitam ser reduzidos e não se reduzem - a um instrumento passivo da classe social que franqueou seu acesso ao poder governamental.

\section{CONSIDERAÇÃO FINAL}

Neste artigo, nós realizamos, pelo menos em parte e partindo do texto de Nicos Poulantzas, a tarefa de discernir os elementos e a dinâmica da crise política de um regime democrático que pode levar à instauração de um governo fascista e, também, à implantação de uma ditadura fascista. Mobilizamos essa ideia para explicar a ascensão do neofascismo no Brasil.

O agravamento dos conflitos de classe e a sua repercussão nas instituições do Estado 
fazem parte de toda crise política. É certo que o tipo de conflito de classe e o tipo de repercussão nas instituições do Estado variam de um tipo de crise para outro. Numa crise revolucionária, quando a continuidade do capitalismo está em questão, as contradições que se agravam são aquelas que opõem o movimento operário ao campo burguês e a repercussão nas instituições do Estado pode significar o esvaziamento da capacidade decisória de todos os ramos do Estado em benefício de um poder alternativo organizado fora dele - um movimento guerrilheiro, um exército popular ou uma rede de conselhos operários e populares. É a clássica situação de duplo poder, quando duas instituições aspiram, representando programas políticos e interesses sociais contraditórios, a soberania sobre um mesmo território. Lênin concebeu e definiu o conceito de crise política revolucionária para explicar a origem das situações de duplo poder. Tal tipo de crise reuniria três características gerais: a) impossibilidade para as classes dominantes de manterem inalterada a forma de dominação; b) piora abrupta das condições de vida das classes dominadas; e c) desenvolvimento acentuado, em virtude das razões anteriores, da atividade das massas empurradas pela crise e pela própria classe dominante "para uma ação histórica independente" (Lênin, 1979, p. 27-28). Evidentemente, cada um desses três elementos exigiria especificações e desenvolvimentos, mas eles fornecem um instrumento eficiente para a análise. O historiador Georges Lefebvre (1939) fez dele, mesmo sem o dizer, um guia esclarecedor e inovador para a análise da Revolução Francesa de $1789 .{ }^{16} \mathrm{O}$ modelo de crise política revolucionária elaborado por Lênin se revelou eficiente para analisar mesmo as revoluções anteriores àquelas ocorridas no século XX.

\footnotetext{
${ }^{16} \mathrm{Na}$ resenha que fez desse livro, o historiador Lucien Febvre enalteceu exatamente o modelo utilizado por Lefebvre para analisar a Revolução, isto é, a caracterização da crise e de sua evolução, como a grande novidade e a grande contribuição do livro: "Nada de mais claro, mais nítido e mais original que o simples esquema da Revolução em 89, tal qual o traça com mãos seguras Georges Lefebvre, conhecedor qualificado dentre todos de nossa história revolucionária" (Febvre, 1940, p. 147, tradução nossa).
}

Numa crise da democracia burguesa, os conflitos que se agravam podem ser de outra natureza, por exemplo, o agravamento dos conflitos entre frações da classe dominante, e a crise institucional, repercutindo esse agravamento, pode se traduzir em mero confronto entre instituições pertencentes ao próprio aparelho de Estado. Mas esse último fenômeno pode ocorrer tanto numa crise política que antecede a implantação de uma ditadura fascista quanto naquela que antecede a implantação de uma ditadura militar. Acreditamos ter fornecido elementos para mostrar que o que há de mais específico na crise pré-fascista talvez se resuma à combinação de quatro dos elementos que examinamos, analisados nas suas relações recíprocas e, também, na dinâmica que tais relações ensejam: crise de hegemonia no bloco no poder, crise de representatividade dos partidos burgueses, situação de derrota do movimento operário e popular que, contudo, permanece ativo e, finalmente, a constituição de uma classe intermediária como força social ativa e reacionária. Espero que o texto tenha fornecido elementos para ligar, um ao outro, cada um desses quatro elementos e para indicar a dinâmica daí resultante.

Recebido para publicação em 27 de fevereiro de 2020 Aceito em 08 de abril de 2021

\section{REFERÊNCIAS}

ADORNO, A. A teoria freudiana e o padrão da propaganda fascista. Margem Esquerda, São Paulo, n. 7, p. 55-78, 2006.

ALTHUSSER, L. Sur la dialectique materialiste. In: ALTHUSSER, L. Pour Marx. Paris: François Maspero, 1965. p. 161-224.

ALVES, J. E. D. O voto evangélico garantiu a eleição de Jair Bolsonaro em 2018. Diário do Centro do Mundo, 2 nov. 2018. Disponível em: https://www.diariodocentrodomundo.com. br/o-voto-evangelico-garantiu-a-eleicao-de-jair-bolsonaroem-2018-por-jose-eustaquio-diniz-alves/. Acesso em: 10 fev. 2019.

AMIN, S. Oltre il capilatismo senile. Milão: Punto Rosso, 2002.

BOEHM, C. Temer diz que Reforma da Previdência será enviada ao Congresso na próxima semana. Brasília, DF: Agência Brasil. 2016. Disponível em: http://agenciabrasil. ebc.com.br/politica/noticia/2016-12/temer-diz-que- 
reforma-da-previdencia-sera-enviada-ao-congresso-naproxima. Acesso em: 20 out. 2019.

BOITO JUNIOR, A. Política neoliberal e sindicalismo no Brasil. São Paulo: Xamã, 1999.

. Reforma e crise política no Brasil: os conflitos de classe nos governos do PT. Campinas: Editora da Unicamp, 2018 .

SédO neofascismo no Brasil. Boletim LIERI, , 1-11, 2019.

CARDOSO, F. H.; FALETTO, E. Dependência $e$ desenvolvimento na América Latina. Rio de Janeiro: Zahar, 1970.

CAVALCANTE, S.; ARIAS, S. A divisão da classe média na crise política brasileira (2013-2016). In: BOUFARTIGUE, P. et al. (org.). O Brasil e a França na mundialização neoliberal: mudanças políticas e contestações sociais. São Paulo: Alameda, 2019. p. 97-127.

DIMITROFF, D. Working class unity-bulwark against fascism: Seventh World Congress of the Communist International. New York: Workers Library Publishers, 1935.

DUMENIL, G.; LÉVY, D. O imperialismo na era neoliberal. Crítica Marxista, Campinas, n. 18, p. 11-36, 2004.

ECO, U. Il fascismo eterno. Milão: La Nave di Teseo, 2017.

EVANS, P. A tríplice aliança: as multinacionais, as estatais e o capital nacional no desenvolvimento dependente brasileiro. Rio de Janeiro: Zahar, 1980.

FARIAS, F. P. Estado burguês e classes dominantes no Brasil (1930-1964). Curitiba: CRV, 2018.

FEBVRE, L. Quatre-vingt-neuf. Annales d'Histoire Sociale, Paris, n. 2, p. 146-148, 1940.

FERNANDES, F. Capitalismo dependente e classes sociais na América Latina. Rio de Janeiro: Zahar, 1973.

GALVÃO, A. As classes médias na crise política brasileira. Blog Junho, [s. l], 27 jun. 2016. Disponível em: http:// blogjunho.com.br/as-classes-medias-na-crise-politicabrasileira. Acesso em: 2 ago. 2019.

GENTILE, E. Chi è fascista. Roma: Laterza, 2019.

GRAMSCI, A. I due fascismi. In: GRAMSCI, A. Sul fascismo. Roma: Riuniti, 1973. p. 133-136.

GUERRIN, D. Fascisme et grand capital. 2. ed. Paris: François Maspero, 1965 [1936].
GUILMO, N. O capital internacional como agente político no Brasil. Campinas: Mimeo, 2019.

HILFERDING, R. O capital financeiro. São Paulo: Nova Cultural, 1985.

LEFEBVRE, G. Quatre vingt neuf. Paris: Maison du Livre Français, 1939.

LÊNIN, V. A falência da II Internacional. São Paulo: Kairós, 1979.

MOORE JUNIOR, B. Injustiça: as bases sociais da obediência e da revolta. São Paulo: Brasiliense, 1987.

NARCISO, P. O pré-sal em disputa: petróleo e burguesia no segundo Governo Lula. 2019. Dissertação (Mestrado em Sociologia) - Universidade Federal de Pelotas, Pelotas, 2019

PAXTON, R. O. The anatomy of fascism. New York: Alfred A. Knopf, 2004.

POULANTZAS, N. Pouvoir politique et classes sociales. Paris: François Maspero, 1968. 1970.

Fascisme et dictature. Paris: François Maspero,

PRADO JUNIOR, C. A revolução brasileira. São Paulo: Brasiliense, 1966.

PRANDI, R. Os $12 \%$ do presidente: em que lugar da sociedade habita o bolsonarista convicto? Jornal da USP, São Paulo, 13 set. 2019. Disponível em: jornal.usp. $\mathrm{br} / \mathrm{p}=272283$. Acesso em: 20 set. 2019 .

REICH, W. La psychologie de masse du fascism. 2. ed. Paris: Payot, 1972 [1936].

SHIRER, W. Ascensão e queda do Terceiro Reich. 2. ed. Rio de Janeiro: Nova Fronteira, 2017.

SINGER, A. O lulismo em crise: um quebra-cabeça do período Dilma (2011-2016). São Paulo: Companhia das Letras, 2018.

TOGLIATTI, P. Corso sugli avversari: le lezioni sul fascismo. Torino: Einaudi, 2010.

TROTSKY, L. Revolução e contra-revolução. 2. ed. Rio de Janeiro: Laemmert, 1968 [1933].

VALLE, A. Divisão e reunificação do capital financeiro: do impeachment ao governo Temer. 2019. Dissertação (Mestrado em Ciência Política) - Universidade Estadual de Campinas, Campinas, 2019. 


\section{THE BRAZILIAN PATH TO FASCISM}

\author{
Armando Boito Jr.
}

The article analyzes the nature of the Bolsonaro Government, its most active social base of support, and the political crisis that gave rise to it. It polemizes with the classical and current bibliography on fascism and, operating with a concept of fascism embedded in the Marxist tradition, characterizes the government and its social base as (neo)fascists. It argues for the need to develop a typology of political crises in capitalist societies, showing that the nature and dynamics of the 2015-2018 Brazilian political crisis are typical of the political crisis that gives rise to fascism. Finally, it places bolsonarismo in the context of the democracy still existing in Brazil, which it characterizes as a bourgeois democracy in crisis.

KEYwORDs: Brazilian Politics. Bolsonaro Government. Neo-fascism. Political Crisis.

\section{LE CHEMIN BRÉSILIEN VERS LE FACISME}

\author{
Armando Boito Jr.
}

Larticle analyse la nature du gouvernement Bolsonaro, sa base sociale de soutien la plus active et la crise politique qui les a engendrés. Il polémique avec la bibliographie classique et actuelle sur le fascisme et, opérant avec un concept de fascisme ancré dans la tradition marxiste, caractérise le gouvernement et sa base sociale comme (néo) fascistes. Il soutient le besoin de développer une typologie des crises politiques dans les sociétés capitalistes et entend montrer que la nature at dynamique de la crise politique brésilienne de 20152018 sont typiques de celle qui donne naissance au fascisme. Il place le bolsonarisme dans le contexte de la démocratie existant encore au Brésil, qu’il caractérise comme une démocratie bourgeoise en crise.

Mots-CLÉs: Politique Brésilienne. Gouvernement Bolsonaro. Néofascisme. Crise Politique.

Armando Boito Jr. - Doutor em Sociologia (USP). Pós-doutorado (Fondation Nationale des Sciences Politiques - FNSP, Paris). Livre-docente (Unicamp). Pprofessor titular (Unicamp), academic visitor na University of London e professor visitante sênior na Fondazione Gramsci - Roma. Professor titular de Ciência Política da Unicamp. Editor da revista Crítica Marxista e dirige a Coleção Marx 21, publicada pela Editora da Unicamp. Coordenou o projeto temático intitulado "Política e classes sociais no capitalismo neoliberal" (Fapesp) e o projeto "Mundialização neoliberal, política e conflitos sociais no Brasil e na França" (Capes-Cofecub). Autor dos livros O Golpe de 1954: a burguesia contra o populismo (Editora Brasiliense); $O$ sindicalismo de Estado no Brasil: uma análise crítica da estrutura sindical (Editora da Unicamp); Política neoliberal e sindicalismo no Brasil (Editora Xamã); $O$ sindicalismo na política brasileira (Editora IFCH-Unicamp); Estado, política e classes sociais (Editora da Unesp) e Reforma e crise política no Brasil: os conflitos de classe nos governos do PT (Editora da Unicamp e Unesp); Dilma, Temer e Bolsonaro: crise, ruptura e tendências na política brasileria (Editora Phillos). 
